\title{
The Influence of Christianity on the Philosophy of John Rawls
}

\author{
MARKo JAKIĆ* \\ • https://doi.org/10.31823/d.29.3.1 • \\ UDK: $1: 27^{*} 32$ - Original Scientific Paper \\ Received: $13^{\text {th }}$ October 2020 • Accepted: $21^{\text {st }}$ April 2021
}

Summary: This article is about a contrastive analysis of Rawls's views in mutually different periods of his philosophical development in relation to possible influences of Christian thought on his overall philosophy. The evidence of such Christian influence on his philosophy is conducted through his examination of sociability and morality as an essential ontological feature of a human being. The second principle of justice is especially emphasized as a view that has a source in Christian thought.

Keywords: Christianity, sociability, morality, justice, personalism, intuition, inequalities, self-respect.

* Marko Jakić, Ph.D., Faculty of Humanities and Social Sciences in Split, University of Split, Poljička cesta 35,

21000 Split, Croatia, marko.jakic84@ gmail.com

\section{Introduction}

When considering the supposed influence of Christian thought on Rawls's philosophy it is advisable to start from the facts which, in a certain way, focus on the possibility of these influences. Directly established facts show as follows:

In his youth, Rawls was about to be ordained as a Protestant priest. ${ }^{1}$ This fact itself does not imply any intellectual connection to his later philosophy but there is certainly a causal relationship with the fact that he studied theology at Princeton University. Rawls finished this course in 1943 by defending his thesis called: A Brief Inquiry into the Meaning of $\operatorname{Sin} \&$ Faith. However, in these war times, instead of

${ }^{1}$ Rawls was born into a family which, in a religious sense, belonged to Episcopal Church in Baltimore. 
being ordained, he joined the army and was an active participant in Pacific War operations of the United States Army until the end of World War II. Traumatic war experiences and news about mass war crimes changed his perspective. In the postwar period, he no longer considered himself as a member of a certain Church. This fact, per se, does not mean Rawls completely changed his attitude on Christianity in a way that there was nothing left. Nevertheless, there is at least one fact that can prove the assumption about the possible influence of Christian thought on his later philosophy. Moreover, this fact can confirm the claim about his later persistence on Christian values. That fact is a manuscript that certainly opens possibilities of research in this matter. Rawls's thesis and his unpublished manuscript from a later period were published in 2010 with a title: A Brief Inquiry into the Meaning of Sin \& Faith with $\gg O n$ My Religion «. In this manuscript Rawls wrote:

$\gg($... ) the content of the judgments of practical reason depends on social facts about how human beings are related in society and to one another. The divine practical reason will also connect with these facts, just as ours does; and this is so even if these facts are themselves the outcome of God's creation. Given these facts as they undeniably are in our social world, the basic judgments of reasonableness must be the same, made by God's reason or by ours. This invariant content of reasonableness without which our thought collapses - doesn't allow otherwise, however pious it might seem to attribute everything to the divine will. So, I go along with Bodin [Refers to Jean Bodin (1530-1596), French philosopher] this far: atheism (as he understands it) is a disaster, but nontheism need not be feared, politically speaking.« (A Brief Inquiry 269)

In this article, indirect facts which can expose the influence of Christianity on his later philosophy are yet to be extracted. In other words, a basic analysis of Rawls's attitudes which, in its content, give evidence to support the influence of Christian thought on his philosophy is the main task of this article.

The research method used in this analysis is an analytic-synthetic method. The analytic part is based on recognizing the semantic correlation of meaning of concept's features which are defined by contextuality of Rawls's relational theoretical utterances. The synthetic part is based on the possibility of meaningful junction of definitions through previously extracted homogeneity of problem units' content features presented in Rawls's different stages of development as different theoretical utterances. As such, texts which belong to Rawls's early stage of research are considered as contextually different in relation to texts which belong to later stages of his researches. So, the analysis of meaning is conducted in mutually different chronological and developing contexts of Rawls's philosophical thought. Con- 
cluding syntheses are generated in order to substantiate presupposed influence of Christian thought on later periods of his philosophy. It was possible to name this substantiation synthetic because views presented in his later work were not possible to be analytically derived from his views in early works.

The structural aspect of this methodological procedure was aiming at extracting some basic metaphysical and ontological assumptions in problem units which are evident in all phases of the development of his philosophy. ${ }^{2}$ Thereby it was necessary to start with indisputable starting points of research. These starting points were found in the fact that his overall philosophy has two problem units. These are views on sociability and views on morality.

When considering the influence of Christian thought on Rawls's philosophy, the valuable contributions of Paul J. Weithman and Dariusz Dankowski should be highlighted. Considering the research undertaken in this article, the following should be noted: Weithman focused on researching ethical issues in Rawls's philosophy, inspired by the views of Joshua Cohen and Thomas $\mathrm{Nagel}^{3}$ who argued that the $\gg$ religious temperament « that existed in Rawls's early writings could also be recognized in A Theory of Justice. Nagel's claim, Cohen's critique, and Rawls's responses to Cohen, ${ }^{4}$ led Weithman to explore further possible religious motives in Rawls's philosophy. ${ }^{5}$ Weithman assesses the impact of Kant's ethical thought on the foundations of Rawls's theory, as Rawls has repeatedly indicated his recognition of religious elements in Kant's Critique of Practical Reason. Since there is a Kantian interpretation of Rawls's ethical foundation, i.e. sense of justice, and a sense of recognition of religious elements in Kant's Critique of Practical Reason, Weithman considers whether there is a possibility of recognizing religious elements in Rawls's intelligible sense of justice. Weithman answers this question in the affirmative sense

\footnotetext{
${ }^{2}$ Here I differ metaphysical and ontological structural aspects of philosophical theoretical utterances. Metaphysics ( $\mu \varepsilon \tau \dot{\alpha}$ and $\tau \dot{\alpha} \varphi v \sigma \iota \kappa \dot{\text { ) }}$ refers to exploring what is outside of sensible experience, what is beyond experience, i.e., what is beyond physics. Metaphysics studies beings starting from existence, searching for first and universal origins (principles are often, in individual philosophical systems, in terms of their metaphysical grounds, enabled by originations) which established overall being. Ontology ( $o^{\prime} v \tau \omega \varsigma$ and $\left.\lambda o ́ \gamma o \varsigma\right)$ refers to the philosophy of being. According to the Greek term, ontology is a study of being, i.e., a philosophy which studies the inner principles (logos) of being. By relying on these determinations, I hold the view that the ontological study of being does not exclude studying its basic features.

${ }^{3}$ See: Thomas Nagel and Joshua Cohen preface in: Rawls, John. A Brief Inquiry into the Meaning of Sinn \& Faith with 'On My Religion'. Harvard University Press, 2010.

${ }^{4}$ See: Cohen, Philosophy, Politics, Democracy 38f. Rawls, Political Liberalism 115f. Cohen, $\gg$ Moral Pluralism and Political Consensus $\ll 283 \mathrm{f}$.

${ }^{5}$ See: Weithman.
} 
that it is not possible to imagine a Christianity that would deny the human being the capacity for a sense of justice. He concludes that there is an agreement between Christian ethical thought and Rawls's ethical foundation. ${ }^{6}$ Dariusz Dankowski highlights the great political and cultural contribution of Rawls's philosophy to contemporary debates on the relationship between Christianity and democracy in the pluralistic societies of Western civilization. ${ }^{7}$ By analyzing Rawls's construction of the social contract, he established a higher level of social adequacy of Rawls's idea of overlapping consensus in relation to Habermas's idea of networks of communicative action. ${ }^{8}$ He concludes that Rawls's philosophy offers compelling reasons in support of the claim that the religious argument may be an important factor in the debates present in contemporary political philosophy. But neither Weithman nor Dankowski engaged in an analysis of the extent to which (due to the fact of the existence of Kantian interpretation of Rawls's ethical foundation) Kantian interpretation of Rawls's principles of justice is possible. In this paper, I prove that Rawls's second principle of justice cannot be derived from Kant's philosophy. That is, I prove that Rawls's idea of the second principle of justice is influenced by Christian ethical thought. This does not invalidate the fact that both of Rawls's principles of justice are consequently in contextual agreement with Kant's categorical imperative since there is a causal Kantian interpretation of Rawls's ethical foundation. But a parallel contextual agreement with Kant's view is proved to cease when it comes to Rawls's second principle of justice.

\section{The influence of Christian thought on Rawls's notion of sociability}

The notion of sociability as a basic ontological feature of human beings is obvious in the early period of Rawls's thought even from the title of his thesis. Here, the meaning of concepts of sin and faith are relationally specified through the notion of society. This consideration of the meaning of sin and faith from a social standpoint led Rawls into stressing the priority of sociability as a human feature even in relation to the feature of reasonableness:

>First of all, what is man? We believe that man is a communal being and thereby possesses personality. The distinctive thing about man is not his reason, not his appreciation of beauty, not his various powers; no, man's distinctiveness from other worldly creatures is that he was made for com-

\footnotetext{
${ }^{6}$ For detailed information see: Jakić, »Osvrt na knjigu Paula J. Weithmana 'Rawls, Political Liberalism and Reasonable Faith'« 105-109.

${ }^{7}$ See: Dankowski.

${ }^{8}$ For more details on Habermas-Rawls debate see: Jakić, Sloboda, pravednost i demokracija 270-393.
} 
munity and that he is a personality necessarily related to community.« (A Brief Inquiry 121)

Here it is certain that Rawls's determination of reasonableness cannot be a final differentiating feature of individuals within our species. No one is more or less human depending on the level of reasoning capabilities. The differentiating feature, in terms of distinguishing our individual personalities, is only partly dependent on personal reasoning capabilities. When distinguishing personalities, personal reasoning capability is equally involved as our associative cognition, our personal emotional experiences, and our personal life goals. This personal distinctiveness, according to Rawls, is possible only because of our feature of being social. As Rawls stated, the development of various personal differences is not possible outside of society and free development of such differences vastly depends on the shape and characteristics of collective organization. Thus, sociability in this developmental aspect conditions the very existence of personal differences. In other words, the possibility of developing one's personality depends on social circumstances. The quality of sociability, which was organizationally realistically established in historically formed forms of sociability, enables or prevents a free development of mutually different and thus authentic personalities. However, in Christianity, the final form of $\gg$ free « personality development, which would as well include an individual's high-handedness as an obstacle for developing other personalities, is limited by the meaning of notions of sin and faith. Thus, a sin is an act against the idea of sociability which is taught by religion. Here, Rawls's trust in social teachings of faith is based at least on social limitations presented in the Ten Commandments (commandments as opposed to high-handedness) and on Christ's teaching about the rightfulness of actions taken upon people in immediate social surrounding (selflessness and helping, love and forgiveness). In this sense, young Rawls said:

»Christian morality is morality in community, whether it be the earthly community or the heavenly community. Man is a moral being because he is a communal being (...) What is sin? We believe that sin is the destruction, annihilation, and repudiation of community. Any action which destroys community is a sinful action. Therefore, the denial of obligations, the refusal to answer to givingness (love), and the rupturing of any personal relations are the acts of the sinner.« (A Brief Inquiry 122)

Much later, Rawls commented on Madison's ${ }^{9}$ arguments supporting early Christianity against the hostile Roman Empire. Many, if not all these arguments, as Rawls claims, can be expressed in categories of political values of public reason. He also

\footnotetext{
${ }^{9}$ Refers to James Madison (1751-1835), fourth president of the USA.
} 
emphasized that reasoning in public reason is not finished once and for all, as it is not finished in any type of reasoning. Moreover, the request of the non-public reason of the Catholic Church that its members follow its doctrine is completely complementary with the idea that they also respect public reason (The Law of Peoples 165, 170).

The comparison of these Rawls's views, presented in his thematically different contexts, shows that Christian values are part of public reason's content in democratic societies of Western civilization. Christian respect for obligations, effort in acts of love and improving personal relations with unselfish aid can be expressed in terms of political values of public reason. Democratic guarantee of freedom of thought aligns the demands of the Catholic Church for its believers to follow the doctrinal beliefs with publicly expressed reason. In addition, since reasoning in public reason is not completed once for all, the demands of non-public reason can once become a part of a public reason. But, only in congruence with reasoning as a result of freely and publicly presented counter-argument and in accordance with free decisions of citizens. Public reason, as a learned social value, finally depends on free decisions made by citizens, i.e., depends on decisions made in accordance with clearly established democratic procedures. In well-ordered societies, public reason definitely excludes any violent acts and/or undemocratic obtrusions.

From previously stated views it is obvious that Rawls would not go so far as to deny the feature of reasonableness as a distinctive mark that differentiates us as a species from any other species in the nature of existing beings. Thus, no spirituality would be possible to express, at least not in words, without reasonableness. No act of love would be possible without the intellectually contemplated intention of such an act. No publicly expressed reason as a democratic acquired social value, which was agreed on by members of mutually different comprehensive doctrines existing in democratic societies, would be possible without argumentative, freely expressed, and publicly available rational reasoning.

Therefore, in the early period of his philosophical development, Rawls relied on social teachings of faith when discussing sociability. In later period, he relied on public reason as an acquired social value. To point out, Christian values are embedded in social values of public reason-as its important valued part.

Since Rawls certainly had to establish sociability in accordance with reasonableness, he had to define human society in a specific differentiating manner. In the early phase, he expressed this special differentiating determination by means of conditioning the link between society and the individual. The existence of human society is as unique world fact as it is every single person individually. Human society exceeds the aggregate of individuality since it is a spiritual area (spiritual realm) 
which at the same time extends and transcends the natural cosmos (Rawls, A Brief Inquiry 111f, 121). The differentiating idea of this, in its core unique transcending, young Rawls expressed with the aid of criticism of Plato's understanding of the way in which sociability conditions morality. To comprehend the meaning of this criticism, we first have to specify Rawls's notion of the relationship between sociability and morality, his idea of $\gg$ naturalism « and finally his understanding of means by which spirituality extends, and with this surpasses, the natural order of cosmos. Young Rawls explains the relationship between sociability and morality as follows:

$\gg$ There is no morality in isolation, except for natural morality, i.e., the morality which concerns the proper objects of appetitions (...). Man is a moral being because he is a communal being. Man is a communal being by nature.« (A Brief Inquiry 122)

Here $\gg$ natural morality $\ll$, in search for an adjustable object of desire, is conditioned by what young Rawls named »naturalistic « view. Naturalism: in which objects of desire belong to the natural cosmos. Thus, the naturalistic perception of morality is individualistic morality. It is determined by its focus on objects outside of a man and thus it is conditioned by objects which do not belong to interpersonal moral relations. The difference between the individualistic idea of morality and the personal idea of morality is certain: individualistic morality is determined by subject-object relation, while personal morality is determined by subject-subject relation.

Rawls agreed with Plato's view that knowledge is a virtue ${ }^{10}$ and that the search for knowledge is a part of human nature. However, he disagreed with Plato's assimilating influence of external objects (adjustable objects of desire) which significantly determine the shape of human characters. Plato's ethics is individualistic because it stays within the frames of naturalism which determines morality only through the state of things that belong to the natural cosmos. Rawls was certainly dissatisfied by the lack of interpersonal moral relations which rely on human nature in a far more complex way. In other words, the lack of spiritual features, which determine interpersonal moral relations, reduces social relationships to desirable material natural goods. He stresses the following:

$\gg$ Personal relations open us to the realm of spirit; natural relations to the realm of nature; and because man participates in both realms, he is the peculiar creature that he is.« (A Brief Inquiry 119)

Rawls's objection to Plato was not aimed at denying social values of desirable things that belong to the natural cosmos, i.e., the area of material, but it was aimed at criticizing the lack of interpersonal morality, i.e., spirituality. Much later, in A Theory of

${ }^{10}$ Socrates was the first to declare knowledge as a virtue. 
Justice, this view became crucial for his determination of the axiological hierarchy of social goods.

Rawls continued with the description of the naturalistically understood cosmos as follows: The influence of Plato's attitude about assimilating the role of external objects on individuals' characters led to an error of reducing personality to desire conditioned by an object. Accordingly, these individualistically understood external objects of desire are extended to a cosmic scale-by extending naturalistically understood subject-object relation. This extension also made God a final object of desire as a part of the naturalistic idea of the cosmos.

$\gg$ While repudiating the extended natural cosmos we do not repudiate nature as such. Man does possess appetitions by nature and desires for food and drink, for beauty, and for truth and thus for the goods of nature as a whole. These desires are good and their objects are good (...). The error lies, not in accepting nature, but in extending natural relations to include all of those in the cosmos. We are mistaken if we think of God as another object of desire. We thereby make Him a part of nature.« (Rawls, A Brief Inquiry 120f)

At first sight, it could seem that Rawls's term »a part of nature « accuses Platonists of one of idealistic versions of pantheism. ${ }^{11}$ But, with this criticism, Rawls did not state, or tried to state, that Platonist thought in any way entails any kind of pantheism. In other words, here Rawls did not try to say that Plato's philosophy could support a thesis which implies God as literally an immaterial part of material nature. In Plato's philosophy, what is perfect and eternal (and is only intelligibly reachable) could not be realized in any way in a variable material cosmos. Otherwise, an imperfect copy would, in an incoherent way, contain perfection as its part. In Plato's philosophy, things are exactly the opposite. Moreover, Platonists studied Plato's philosophy concurring with Cassiodorus's view that Plato spoke of what is perfect, eternal, and intelligible in a superior way. Concerning this Copleston states as follows:

>In his De anima Cassiodorus drew on St. Augustine and on Claudianus Mamertus (died c. 474) in proving the spirituality of the human soul. While the soul cannot be a part of God, since it is changeable and capable of evil, it is not material and cannot be material, since it can have what is spiritual as the object of its knowledge, and only that which is itself spiritual can know the spiritual.« (Copleston 104f)

\footnotetext{
${ }^{11}$ Here it is possible to think of Schelling's version of pantheism.
} 
This certainly implies that Cassiodorus's thought is incompatible with any form of pantheism, but it is, without doubt, compatible with Plato's philosophy; namely, what is imperfect cannot be a part of perfection. In Rawls's overall philosophy, nothing implies that he was not aware of these facts about Plato and Platonists. By criticizing $\gg$ naturalism $\ll$ Rawls intended to show something completely different. He expressed his view on an insufficient feature of naturalized relation of desirability. In a social sense, it is insufficient as it takes into account only interpersonal relationships conditioned by material goods. In a philosophical sense, it is insufficient because it stresses only the intelligible (contemplative) part of thought about God. On the other hand, the assumption that Rawls would, with this criticism, maybe supposedly refuse philosophical intellectualism is highly unlikely. In fact, in his whole theory, there is an unbreakable link between reason and compassion (love). This is definitely inconsistent with the pietistic termination of this link. So, Rawls here missed the emphasis on interpersonal relationships conditioned by spirituality and active social deeds focused by social teachings of faith.

Now it is possible to extract the meaning of Rawls's establishment of human society in, previously mentioned, special differentiating way: human society is a unique fact of the world that spiritually surpasses the natural order of cosmos. Spiritual values rooted in society define the rightfulness of social actions. Ways of defining the rightfulness of actions enable or obstruct the free development of individuals. In this sense, the feature of sociability is a basic ontological feature of human beings-it is a requirement for realizing a personality.

Much later, Rawls explained the uniqueness of human society, in terms of exceeding the natural order of cosmos in the context of considering mutually different ideas about justice, in the following way:

$\gg$ A social ideal in turn is connected with a conception of society, a vision of the way in which the aims and purposes of social cooperation are to be understood. The various conceptions of justice are the outgrowth of different notions of society against the background of opposing views of the natural necessities and opportunities of human life.« (A Theory of Justice 9)

The complexity of relationships of spiritual values rooted in society, in the context of considering the role of justice as fairness when it comes to the idea of social unification, he expressed in this way:

$\gg$ Learning from one another's efforts and appreciating their several contributions, human beings gradually build up systems of knowledge and belief; they work out recognized techniques for doing things and elab- 
orate styles of feeling and expression. In these cases, the common aim is often profound and complex, being defined by the respective artistic, scientific, or religious tradition; and to understand this aim often takes years of discipline and study.«(A Theory of Justice 461$)$

Three years before he died, when questioning the idea of public reason, Rawls said that Henry's ${ }^{12}$ argument for state church was based on an attitude that $\gg$ Christian knowledge hath a natural tendency to correct the morals of men, restrain their vices, and preserve the peace of society; which cannot be effected without a competent provision for learned teachers. « According to Rawls, this Henry's argument did not refer to the valuable assessment of Christian cognition but to the efficiency of the ways to practically achieve basic political values. He concluded that Henry considered $\gg$ vices $\ll$, at least partially, as actions opposite to virtues included in political liberalism (The Law of Peoples 165).

Thus, I think we can conclude with a fair certainty that Rawls's idea of social agreement is rooted in those ontologically specifically differentiating and also cognitive valuable attitudes about the human feature of sociability which he expressed in his first period of philosophical development. I also think we can conclude with a similar level of certainty that Christian values influenced a part of this idea. But what are these Christian values? In which way are they included in this idea? Answers to these questions can possibly be found with the help of further contrastive analysis.

\section{The influence of Christian thought on Rawls's second principle of justice}

Rawls's idea of social contract is based on two principles of justice. These principles are: (I) »Each person should have an equal right to the most extensive liberties compatible with similar liberties for all.« (II) »Social and economic inequalities should be arranged so that they are both (a) to the greatest benefit of the least advantaged persons, and (b) attached to offices and positions open to all under conditions of equality of opportunity.« (Rawls, A Theory of Justice 53, 72) It is certain that these two principles are based on the idea of justice. Here justice certainly belongs to the ethical area of research as a philosophical reflection about the concept of morality. It is also certain that the content of the concept of justice is here denoted with features of equality and fairness. It could be assumed that Rawls had a good philosophical reason why he defined justice through its feature of impartiality-justice as fairness. Also, it could be assumed that he had a well-thought reason to make a thesis which implies that the concept of justice has to essentially include

\footnotetext{
${ }^{12}$ Refers to Patrick Henry (1736-1799), an American politician.
} 
the feature of equality in its content. Namely, attempts to historically relativize justice as fairness in the end always stop at borderline theoretical failure, because they regularly paradoxically end with $\gg$ impartial inequality $\ll .{ }^{13}$ This paradox could not satisfy Rawls in a general philosophical sense. So, he approached the theoretical construction of the democratic ideal as an idea of a well-ordered society. In a particular ethical sense, this idea is based on an assumption about the moral obligation of fair social assurance of equal liberties and possibilities for all, and this is, at its core, expressed in his principles of justice.

Now I can focus on Rawls's method of relying on the intuition of justice. In other words, we have to focus on extracting his method of relying on intuition in order to try to extract theoretical sources of this reliance. ${ }^{14}$ Namely, we have to extract the reasons for relying on what Rawls in his work On My Religion defined as an unchangeable content of reasonableness of a practical reason and in A Theory of Justice as a sense of justice, so we could then specify the sources of this reliance.

The reasons for this theoretical reliance on the intuition of justice Rawls expressed in this way:

$\gg$ As I have already remarked, there is nothing necessarily irrational in the appeal to intuition to settle questions of priority. We must recognize the possibility that there is no way to get beyond a plurality of principles. No doubt any conception of justice will have to rely on intuition to some degree. Nevertheless, we should do what we can to reduce the direct appeal to our considered judgments. For if men balance final principles differently, as presumably they often do, then their conceptions of justice are different. The assignment of weights is an essential and not a minor part of a conception of justice. If we cannot explain how these weights are to be determined by reasonable ethical criteria, the means of rational discussion have come to an end. An intuitionist conception of justice is, one might say, but half a conception. We should do what we can to formulate explicit principles for the priority problem, even though the dependence on intuition cannot be eliminated entirely.« (A Theory of Justice 36f)

From this point of view, rationality, and to some extent irremovability, of this appeal to intuition is certain when defining the priority of fundamental principles of

${ }^{13}$ For further explanation of this view see: Jakić, $\gg$ Problem intuicije moralnosti u filozofiji Johna Rawlsa $\ll$ 5-20.

${ }^{14}$ I use the word $\gg$ source $\ll$ in the context of recognizing ideas that could have been acquired and/or passed on throughout history in mutually different theoretical contexts. This meaning of the word in no way implies any type of unoriginality. But it surely directs to theoretical influences which can be found in all philosophical concepts, same as in all paradigms of distinct scientific disciplines. 
justice. Next, if we also cannot explain the means of balancing different concepts of justice by using ethical criteria, it leads to the end of rational discussion about justice. But what is this irremovable intuitive level in the concept of justice and what are these explainable ethical criteria? In other words: Which factor makes intuition irremovable from examination of priority of principles and which factor enables explainable power of ethical criteria?

Now we have to first extract this factor and then reach for Kantian interpretation of it (Rawls, A Theory of Justice 221-227). ${ }^{15}$ Rawls's principles of justice are a result of his thought experiment which he called original position. Participants who decide on principles of justice in the original position are to the highest meaningfully possible extent close to Kant's condition of apriority. They only have at their disposal the information about how they decide about the society that has, in a proprietary economic sense, civil inequality. The factor which allows all participants to agree on principles of justice under these conditions is only one-sameness of their basic intuition of justice. This basic level of intuition in the original position acts completely independent of mutually different social and biological circumstances because of the lack of all such information. With this, we have extracted the factor which, according to Rawls's philosophy, makes intuition irremovable from examination of priority of principles. Namely, we have extracted the factor which enables the power of ethical criteria when explaining the means of balancing mutually different concepts of justice.

In the sense of enabling the explainable power of ethical criteria, Kant marked this factor as the human ability to comprehend the moral good. In other words, Kant called this factor a feeling created by intellectual reason:

>Also ist Achtung fürs moralische Gesetz ein Gefühl, welches durch einen intellektuellen Grund gewirkt wird, und dieses Gefühl ist des einzige, welches wir völlig a priori erkennen, und dessen Notwendigkeit wir einsehen können.« (Kritik der praktischen Vernunft 130)

This capability, i.e., this intellectual feeling as a distinguishing ethical factor, is determined as an autonomous a priori fact $\gg$ factum $\ll$ of a pure practical reason. Recognized in Kant's philosophical concept as Copernican turn: with aid of causal category applied to the imperative as a starting point of transcendental study of moral part of architectonics of pure reason. In other words, research done established human capability of distinguishing good from evil based on unconditioned good:

\footnotetext{
${ }^{15} \mathrm{By} \gg$ Kantian interpretation « I mean views that are in accordance with Kant's philosophy, i.e., views that are not opposite to Kant's philosophy.
} 
$\gg$ Sie sucht als reine praktische Vernunft zu dem praktisch Bedingten (was auf Neigungen und Naturbedürfniß beruht) ebenfalls das Unbedingte, und zwar nicht als Bestimmungsgrund des Willens, sondern, wenn dieser auch (in den moralischen Gesetzen) gegeben worden, die unbedingte Totalität des Gegenstandes der reinen praktischen Vernunft, unter dem Namen des höchsten Guts.« (Kant, Kritik der praktischen Vernunft 194)

The criterion of ethical assessment is discovered when will consciously recognizes itself (it develops itself to a concept) as an absolute autonomous unconditioned good will. ${ }^{16}$ Intellectual sense for moral good as an autonomous a priori fact of pure practical reason functioned completely independent from mutually different posteriori, and consequently from social and biologically conditioned, pathological influence. ${ }^{17}$ Kant's condition of a priori required the absolute independence (autonomy) of this human intellectual ability from any empirical content. But the categorical imperative, as an expressive formulation of the duty of moral action in accordance with this a priori intellectual ability, had to distinguish moral good from evil in practice. Rawls also adopted this practical condition in his thought experiment, since, without basic information about the structure of the society they decide on, participants in their original position would have nothing to decide. But because of this practical condition, a utilitarian critique followed. It stated that participants in Rawls's original position could not make a morally autonomous decision in choosing the principle of justice. A more comprehensive utilitarian critique was developed and it denied Rawls's original position that:

(a) In order for the participants in Rawls's thought experiment to rely on a sense of justice at all when deciding to adopt the principle of justice, they would rely solely on their egoistic interests. ${ }^{18}$ (b) That the decision of the participants in Rawls's thought experiment, in adopting the principle of justice, could be morally autonomous at all, but could only be morally heteronomous. ${ }^{19}$ (c) For Rawls's construction of the social contract to be realistically feasible to any extent at all, since it can only belong to scientific anti-realism..$^{20}$ (d) In order for the participants in Rawls's

\footnotetext{
${ }^{16}$ Kant's sentence that there is nothing good in the world but good will is very famous. Thus, in this world, every other good is good for something else.

${ }^{17}$ Kant uses the term $\gg$ pathological influence $\ll$ for conditioning a priori given facts by posteriori given facts.

${ }^{18}$ See: Nozick 33f; Singer 19-25.

${ }^{19}$ See: Jonson 58-66; Krasnoff 399-402

${ }^{20}$ See: Hare 144-145, 241-252; O'Neil 69-85.
} 
thought experiment to have convincingly any particular reason to choose the principles of justice, and not to choose the utilitarian principle of happiness. ${ }^{21}$

In relation to the objection (a), critics may be told that egoistic participants in thought experiments, precisely because of their purely egoistic interests, would not adopt any moral principles and then not even Rawls's principles of justice. ${ }^{22}$ In relation to objection (b), it may be answered that the condition of practicality existing in both Kant's and Rawls's philosophy of morality is a necessary and inescapable condition for any meaningful reflection on morality. This condition makes neither Kant's categorical imperative nor Rawls's principles of justice non-autonomous. Namely, they are based on an autonomous intelligible sense. In Kantian manner: If participants in Rawls's original position were pathologically affected by a practical condition because they have information to decide on principles for a democratic society in which there are inequalities in material property, then any practical application of Kant's categorical imperative would also be pathologically affected by that practical application itself. But the condition of applicability in practice leads neither Kant's categorical imperative nor Rawls's principles of justice to heteronomy. The guarantor of their autonomy is their a priori foundation. With respect to objection (c), the answer may be that Rawls's constructions are exactly as scientifically antirealistic as the scientifically antirealistic constructions of evidence in mathematical theory. In relation to objection (d), the answer can be that the utilitarian principle of happiness is part of a morally neutral theory and does not particularly require a democratic social order. ${ }^{23}$ This is a special and compelling reason for choosing Rawls's principles of justice. These, at this point brief, responses to utilitarian objections (a)-(d) are consistent with Kaufman's view of utilitarian critique with which I fully agree. ${ }^{24}$

So, the factor which makes intuition irremovable from analyzing morality and which enables ethical criteria of morality is recognized in Rawls's philosophy as an intelligible sense of justice, and in Kant's philosophy as an intelligible sense for moral good. ${ }^{25}$

${ }^{21}$ See: Smart 103-15; Parfit 137-68.

${ }^{22}$ For an argument in support of this view see: Jakić, Sloboda, pravednost i demokracija 187-205.

${ }^{23}$ For a detailed explanation of this view see: Jakić, Sloboda, pravednost i demokracija 34-36.

${ }^{24}$ See: Kaufman 227-256.

25 The factor that makes intuition inseparable from the consideration of morality is certainly found in Christian thought based on Holy Scripture. But this does not allow the synthesis of Kant's philosophy and Christian thought. Namely, the synthesis of Kant's philosophy and Christian thought is by no means inconsistently possible due to the incompatibility of mutually logically opposite views. In Christianity, God created the World, and traces of his plan can be recognized in the arrangement of the World. In Kant's philosophy of the ordering of the World, we can neither affirm nor deny the existence of God. In Christianity, God has endowed man with the ability to distinguish moral good 
I think this fundamental link between Rawls's and Kant's philosophy of morality could be denied only by the absurd assumption that justice is not morally good.

Now we can shortly reflect on the possibilities of Kantian interpretation of Rawls's principles of justice. Kantian interpretation of Rawls's first principle of justice is established through homogeneity of Rawls's and Kant's fundamental intuitive factor of morality. Namely, I establish it with the help of Kant's definition of intelligible sense for moral good which, as an autonomous fact of practical reason, founded his ethics of duty. Indeed, this fact about clear practical reason surely refers to every individual; every person according to this fact is the same and is equally faced with freedom of moral choice. ${ }^{26}$ This interpretation of the first principle of justice shows that Rawls, in comparison to Kant's philosophy, through the same moral intuitive factor, expressed a demand for impartial assurance of civil equality for all individuals. ${ }^{27}$ The moral source of the first principle of justice is, thus, possible to be interpreted to the full in a Kantian manner. The second principle of justice demands that social and economic inequalities should be organized in such a way that they are the most useful to people in the least favorable position and that they are connected to positions and services available for all under conditions of im-

from evil, thus making him a free being who is responsible for the choice of his actions. In Kant's philosophy, man's ability to distinguish moral good from evil is the a priori rational content of his pure mind, and it is man's rational duty to follow the choice of moral law. Since man is certainly a part of the World, Kant could not argue that the ability to distinguish moral good from evil is given to man by God without establishing a contradiction with his view that from the order of the World we can neither confirm nor deny God's existence. This impossibility of deciding on God's existence on the basis of the arrangement of the World, as a point of view existing in Kant's philosophy, is confirmed by the encyclopedic literature. See: Stanford Encyclopedia of Philosophy (God in the Critique of Pure Reason's Transcendental Dialectic), Internet Encyclopedia of Philosophy (Immanuel Kant: Philosophy of Religion), Catholic Encyclopedia (Philosophy of Immanuel Kant). In this article, I am far from establishing a $\gg$ synthesis $\ll$ that would fundamentally contain inconsistencies in sole relation to Kant's philosophy. But the impossibility of a contradictory synthesis of Kant's philosophy and Christian thought in no way affects the possibility of mutually different philosophical reliance on man's moral intuition in theoretically and practically different ways. The reliance on man's moral intuition has been theoretically further developed in different ways in Christian thought, in Kant's philosophy, and in Rawls's philosophy. Rawls's recognition of religious elements in Kant's »Critique of the Practical Reason « did not at all require a contradictory »synthesis « of Kant's philosophy of morality and Christian ethical thought. Just as the thesis that states that Rawls's second principle of justice cannot be derived from Kant's philosophy, but can be derived from Rawls's conception of Christianity, as I am proving here, does not at all require this $\gg$ synthesis « which cannot uncontroversially establish Rawls' idea of principles of justice.

${ }^{26}$ Otherwise, categorical imperative as a law of freedom could not practically separate good from evil since Kant's moral »general legislature « would remain, indeed, pointlessly empty.

${ }^{27}$ By civil equality I mean values of human rights and freedoms; in a wide range from gender equality, freedom of speech and movement to rights to education and medical care. 
partial equalities and possibilities. This principle was chosen by participants in the original position as a reasonable inevitable condition of trying to realize the first principle of justice. In fact, demanding equal rights to the widest scheme of basic equal freedoms, which is compatible with a similar scheme of freedom for others, in a society in which there is a class that barely survives, is absolutely unreasonable. Those with the least favorable social status and their biological descendants would not be able to, for example, pay a decent pension fund and health care, nor would they be able to ensure their children a higher level of education for generations. For those, a proclaimed first principle of justice that guarantees impartial rights to the widest scheme of basic freedoms would only be a dead letter. ${ }^{28}$ Interdependence of the first and the second principle of justice is a matter of reasonably well-thought arguments. These arguments are not interdependent in an analytical way; the demand for normative insurance of basic freedoms is not analytically followed by the demand for distinctive distribution of resources, nor is the demand for distinctive distribution of resources analytically followed by normative insurance of basic freedoms. Furthermore, these arguments do not require any special reference to Kant's philosophy. They are mutually synthetically conditioned but not through Kantian interpretation of the first principle of justice. Thus, because of the synthetic nature of mutual conditioning arguments, we must try out a special Kantian interpretation of the second principle of justice.

Let us show to which extent this interpretation is possible. Previously extracted basic intuitive factor, which has already been demonstrated as mutual in Rawls's and Kant's philosophy of morality, could enable it. But now we must reach out for special links of this factor in mutually different contexts of these philosophies. In Rawls's philosophy, this factor grounds the explanatory principle of rightfulness in connection to the feeling of moral shame and feeling of self-worth.

$>$ Now both regret and shame are self-regarding, but shame implies an especially intimate connection with our person and with those upon whom we depend to confirm the sense of our own worth. Also, shame is sometimes a moral feeling, a principle of right being cited to account for it.« (Rawls, A Theory of Justice 388f)

In Kant's philosophy, this factor grounds the principles of actions in connection to the duty of love towards your neighbor and duty of mercy.

\footnotetext{
${ }^{28}$ Some contemporary members of neoliberal ideology are unrelenting in relation to this problem. They resort to »arguments « of laziness and incompetence and the »argument « of eugenic insufficiency: social losers deserve their place in society because of their laziness and incompetence and losers give birth to other losers only.
} 
$\gg$ It is undoubtedly in this way, again, that we are to understand the passages from scripture in which we are commanded to love our neighbor, even our enemy. For, love as an inclination cannot be commanded, but beneficence from duty-even though no inclination impels us to it and, indeed, natural and unconquerable aversion opposes it-is practical and not pathological love, which lies in the will and not in the propensity of feeling in principles of action and not in melting sympathy; and it alone can be commanded.« (Kant, Groundwork 54f)

As follows, the basic intuitive factor of morality Rawls connected to the feeling of self-worth, while Kant connected it to the duty of merciful love. Both connections show practical ways in which this factor grounds the principles which regulate the morality of actions.

The second principle of justice, through Rawls's ontological thesis about the human being, surely includes love towards one's neighbor. Rawls certainly could not extract the demand for social sensibility from egoism and hatred towards one's neighbor. In A Brief Inquiry into the Meaning of Sin and Faith, he marked egoism as a sin against society and in $A$ Theory of Justice, as a negation of morality. The demand for social sensibility cannot stem from sin against society and negation of morality. Thus, love towards your neighbor is surely a part of Rawls's idea about a well-ordered society. As an acquired social value, it is expressed in a well-ordered society by public normative regulation as a duty towards a fellow human. However, with this, we have depleted the possibility of Kantian interpretation of the second principle of justice. In fact, in Kant's philosophy, normative regulation of duty of helping persons with the least favorable social status stops at the level of mercy which assures a mere survival.

»The general will of the people has united itself into a society that is to maintain itself perpetually; and for this end it has submitted itself to the internal authority of the state in order to maintain those members of the society who are unable to maintain themselves. For reasons of state the government is therefore authorized to constrain the wealthy to provide the means of sustenance for those who are unable to provide for even their most necessary natural needs. The wealthy have acquired an obligation to the commonwealth, since they owe their existence to an act of submitting to its protection and care, which they need in order to live; on this obligation the state now bases its right to contribute what is theirs to maintaining their fellow citizens.« (Kant, Groundwork 468)

The difference is unquestionable: in Rawls's philosophy, the demand for public normative regulation of duty of helping persons with the least favorable social sta- 
tus by far surpasses Kant's demand for ensuring means enough to satisfy the most essential natural needs. In the second principle of justice, Rawls demands public normative ensuring of sufficient amount of resources for the impartial provision of social opportunities to all persons to develop to the level of self-respect. ${ }^{29}$ Therefore: The mutually different level of moral demand mirrors the difference between Kant's and Rawls's notions of normative obligation to those in the least favorable social position. This difference points to its own specially extracted original. The original idea of the moral claim expressed in the second principle of justice is found in Rawls's early reliance on the Christian conceived value of the person. The sense of understanding sin and faith, the meaning of the commandment against self-will, the meaning of the spiritual realm that transcends the natural cosmos, and the sense of the moral obligation to actively help the neediest. The Christian values woven into Rawls's conception of the public mind did not impair the autonomy of the participants' decision to choose the second principle of justice in its original position. Rawls thought that the realization of the first principle of justice, based on a sense of justice in a democratic society in which there are inequalities in property, could be achieved with the help of Christian personalistic norms. ${ }^{30}$

\section{Conclusion}

Conducted contrastive analysis of Rawls's views from mutually different stages of his philosophical development shows a significant influence of Christian thought on his overall philosophy. Christian values, in sense of obligation to respect a person, love towards your neighbor, and an obligation to help those with the least favorable social status, are constant moral demands in this philosophy. Rawls intensified these demands to the level of publicly expressed normative regulations within the idea of a well-ordered society. By acquiring the self-respect of a person as the highest social good, he established a personalistic Christian moral norm to the foundations of an idea about the future development of contemporary democratic societies.

So, I think that Rawls's second principle of justice has its source in exactly similar Christian values. As publicly expressed, these values, i.e., values of public reason, preserve this motivation through the principle of difference and for ensuring an opportunity for the development of every person to the level of self-respect.

\footnotetext{
${ }^{29}$ For this reason, Rawls defined self-respect as the most important social good. The axiological source of this reason is stated in the previous subchapter.

${ }^{30}$ I understand personalistic norm in a way similar to Pope John Paul II. See: Wojtyla, $58 \mathrm{f}$.
} 


\section{Works Cited}

Arthur, John and Shaw, H. William, editors. Justice and Economic Distribution. Prentice-Hall Inc., 1978.

Catholic Encyclopedia. https://www.newadvent.org/cathen/12025c.htm. Accessed 18 Jan. 2021.

Cohen, Joshua. »Moral Pluralism and Political Consensus. $\ll$ The Idea of Democracy, edited by David Copp, Jean Hampton, and John E. Roemer, Cambridge University Press, Cambridge, 1993, pp.

---. Philosophy, Politics, Democracy. Harvard, 2009.

Copleston, Frederick. Medieval Philosophy. Continuum, 2003.

Copp, David et al., editors. The Idea of Democracy. Cambridge University Press, 1993.

Dankowski, Dariusz. Rawls on Religion in Public Debate. WAM, Krakow, 2014.

Hare, R. Mervyn. »Rawls' Theory of Justice.« The Philosophical Quarterly, vol. 23, no. 91, 1973, pp. 144-155.

Internet Encylopedia of Philosophy. https://iep.utm.edu/kant-rel/\#H6. Accessed 18 Jan. 2021.

Jakić, Marko. »Osvrt na knjigu Paula J. Weithmana 'Rawls, Political Liberalism and Reasonable Faith.«Zbornik radova Filozofskog fakulteta (10), 2017. pp. 105-109.

---. »Problem intuicije moralnosti u filozofiji Johna Rawlsa.« Nova prisutnost: časopis za intelektualna i duhovna pitanja, vol. 16, no. 1, 2018, pp. 5-20.

---. Sloboda, pravednost i demokracija u filozofiji Johna Rawlsa. Naklada Breza, 2018.

Johnson, A. Oliver. »The Kantian Interpretation.« The Journal of Ethics, vol. 85, no. 1, 1974, pp. 58-66.

Mandle, Jon and Reidy, A. David, editors. The Cambridge Rawls Lexicon. Cambridge University Press, 2014.

Kant, Immanuel. Groundwork of the Metaphysics of Morals, translated by Mary Gregor, Cambridge University Press, 1996.

---. Kritik der praktischen Vernunft. www.gutenberg.org. Accessed 23 May 2020.

Kaufman, Alexander. »Rawls and Kantian Constructivism. Kantian Review, vol. 17, no. 2, 2012, pp. 227-256.

Krasnoff, Larry. Kantian Interpretation. in: Jon Mandle, David A. Reidy editors. The Cambridge Rawls Lexicon. Cambridge University Press, Cambridge, 6. Dec. 2014, p. 399402.

Nozick, Robert. Anarchy, State, and Utopia. Basic Books Inc, New York, 1974.

O’Neil, Onora. Constructing Authorities. Cambridge University Press, Cambridge, 2015.

Parfit, Derek. $\gg$ Later Selves and Moral Principles. $\ll$ Philosophy and Personal Relations, edited by Alan Montefiore, Routledge and Kegan Paul, 1973.

Rawls, John. A Brief Inquiry into the Meaning of Sinn \& Faith with 'On My Religion'. Harvard University Press, 2010. 
---. A Theory of Justice. Harvard University Press, 1971.

---. The Law of Peoples with 'The Idea of Public Reason Revisted'. Harvard University Press, 1999.

---. Political Liberalism. Columbia University Press, 2003.

---. Collected Papers. Harvard University Press, 2001.

Singer, Peter. Rewiew of 'Anarchy, State, and Utopia' by Robert Nozick. The New York Rewiev of Books, New York, 1975.

Smart, C. J. John. Distributive Justice and Utilitarianism. Justice and Economic Distribution, edited by John Arthur, and William H. Shaw, Prentice-Hall Inc., 1978, pp. 103-115.

Stanford Encyclopedia of Philosophy. https://plato.stanford.edu/entries/kant-religion/. Accesed 18. Jan. 2020.

Weithman, Paul. Rawls, Political Liberalism and Reasonable Faith. Cambridge University Press, 2016.

Wojtyla, Karol. Man in the Field of Responsibility. St. Augustine's Press, 2011. 
- M. Jakić, The Influence of Christianity on the Philosophy ..., Str. 299-319.

\title{
UTJECAJ KRŠĆANSTVA NA FILOZOFIJU JOHNA RAWLSA
}

\author{
Marko JAKIĆ*
}

Sažetak: Članak se bavi usporednom analizom Rawlsovih stajališta u međusobno različitim razdobljima njegova filozofskoga razvoja, a u odnosu na moguće utjecaje kršćanske misli na njegovu cjelokupnu filozofiju. Dokazi za kršćanski utjecaj na njegovu filozofiju provedeni su preko njegova istraživanja društvenosti i moralnosti kao bitnih ontologijskih obilježja ljudskoga bića. Drugo načelo pravednosti posebno je istaknuto kao stajalište koje svoj izvornik ima u kršćanskoj misli.

Ključne riječi: kršćanstvo, društvenost, moralnost, pravednost, personalizam, intuicija, nejednakosti, samopoštovanje.

* Dr. sc. Marko Jakić, Filozofski fakultet u Splitu, Sveučilište u Splitu, Poljička cesta 35, 21000 Split, Hrvatska, marko.jakic84@gmail.com 